\title{
DEVELOPMENT OF GROUNDNUT OIL EXPELLING MACHINE
}

\author{
KUKU R.O., ADEFUYE O.A., FADIPE O.L., \\ ADEBOWALE G.I., DELOGAN O.M. \\ Mechanical Engineering Department, Lagos State University, Nigeria
}

\author{
Received: $28^{\text {th }}$ August 2019 \\ Accepted $26^{\text {th }}$ March 2020 \\ Published:20 ${ }^{\text {th }}$ September 2020 \\ https://doi.org/10.47545/etrj.2020.5.2.072
}

\begin{abstract}
The need for new designs of Groundnut oil expeller is based on the cost and efficiency of the machine especially for the usage in small and medium size industries. It has to be cost effective and light weight to accommodate such demands. The existing Groundnut Oil Expellers in the market are too big and too expensive for these small medium size businesses to invest on. Other limitations are its maintenances aspect as well as its operations. Therefore, series of survey and research have been done to identify the needs and base on that, the Final Design and Specifications were synthesized. The Groundnut Oil Expeller is a screw type machine, which presses groundnut through a barrel-like cavity. Raw material (groundnut) enters one side of the press and by product (cake) exit the other side. The machine uses friction and continuous pressure from the screw drives to move and compress the groundnut. The oil seeps through small openings that do not allow groundnut fibre solids to pass through. Afterward, the pressed groundnuts are formed into a hardened cake, which is removed from the machine. This machine will satisfy the demand for the small and medium size industries because of its design, functionality and price. The measurements of the performance also being analyze by calculating the design efficiency.
\end{abstract}

Keywords: Groundnut, extractor, Expeller, Shaft, Machine, Oil

\section{INTRODUCTION}

Oil extraction is the process of recovering oil from oil bearing agricultural products through manual, mechanical, or chemical extraction. The agricultural products are into oil-seeds (cotton, castor, sunflower, and so forth), nuts (coconut, groundnut, shearnut, and so on) and mesocarps or organic products (oil palm). Groundnuts are significant seed utilized for oil extraction, our nation is a bigger maker of groundnuts yet oil extraction in industry is less valuable for farmer and farmer can't separate oil because of restricted assets so our point is to build up a machine which runs on human force and helps simpler oil extraction. There are different strategy for extraction such distillation maceration, extraction of oil by oil seed presser. The human controlled oil seed presser can be utilized to extract oil from seeds for a limited scale amount. For homegrown purposes human mechanical force can be utilized to remove oil from different seeds at a lower scale

Groundnut oil expeller has been developed and built by many researchers in various sizes, shapes and materials, for the most part for industrial uses. Such expellers are costly; include undeniable level innovation which can't be managed by limited scope and low pay oil mill operators. To help the limited scale oil mill operators in the nearby networks, limited scope groundnut oil expellers should be designed, and constructed with locally sourced materials.

Oil Extraction Machines: The mechanical process is a method for oil extraction. Mechanical expression of oil requires the application of pressure to force oil out of the oil-bearing material [1]. Various types of machines can be used for compression: screw presses, hydraulic presses, roll presses and mills, collapsible-plate and frame-filter presses, disc mills, interlocking- finger juice extractors, juice reamers [2]. Pressing technology of oleaginous material meal occurs under the influence of compression forces in mechanical presses. In India, nearly $90 \%$ of the total 24 million tonnes of produced oilseeds are crushed using this method [3].

The safety and simplicity of the entire process is advantageous compared to more efficient solvent extraction equipment. Moreover, in contrast to the solvent extraction method, mechanical pressing yields a chemical free protein rich cake [3],[4]. Mechanical screw presses typically recover 86-92\% of oil from oilseeds [3]. Oil recovery can also be enhanced by suitable pretreatment of the oilseed, such as cleaning, conditioning, decorticating, cracking, flaking, cooking, extruding, and drying to optimal moisture content [5]. 
Eliwa et al, 2012 [6] studied factors which affect the performance of extraction of watermelon seeds and cutting peel machine. The feed rate was varied from $20-40 \mathrm{~kg} / \mathrm{min}$. The seed losses and damage increased with increasing cutting unit speed from 1.11 to $2.59 \mathrm{~m} / \mathrm{s}$ and time-span after harvesting and using concave with square holes. A small-scale equipment for decupling of locust bean seeds it was found out that the speeds of the operation of the depulpping machine affect the magnitude of deppulping efficiency and membrane detachment efficiency. The effect of the machine speed has no significant influence on the percentage seed loss. The soaking time has direct influence on the magnitude of seed membrane detachment efficiency [7].

An Expelling machine for extracting oil from soya bean seed was designed and fabricated [8]. The expelling unit consists of a screw expellant shaft with expellant barrel. The results obtained from the developed machine shows that mechanical extraction is a suitable method for extracting soya bean oil because of its high yield and high oil purity. Ojolo et al.,2012 [9] studied the design of an efficient Jatropha oil expelling machine The Jatropha oil expelling machine has been designed to a capacity of $1000 \mathrm{~kg} / \mathrm{hr}$ and can expel oil at the rate of $2.2 \mathrm{~m} 3 / \mathrm{hr}$. The machine is powered using electric motor of $40 \mathrm{~kW}$ to be operated for 8 working hours. The designs of the crusher and pre-heating systems before pressing enhanced the performance of the expeller and the machine could deliver greater than $90 \%$ efficiency.

(Chaimae, 2016) [10] did the coffee oil extraction was carried out using n-hexane as the solvent. Heating and ultra-sonication were included in the oil extraction phase of the experimental work to reduce the duration of chemical reactions. The maximum yield of coffee oil extraction that could be achieved was $8.9 \%$ with $66 \%$ solvent recovery. It has been possible to extract coffee oil with a yield of $8.9 \%$ and $69 \%$ of hexane recovery. An Oil Extraction Machine was developed for extracting oil from Cashew Nut Shell. The extracting unit consists of an auger with decreasing pitches. An Oil Extraction Machine for Cashew Nut Shell with a capacity of 100, $33 \pm$ $0,577 \mathrm{~kg} / \mathrm{hr}$. was developed. Evaluation of the machine on Cashew Nut Shell gave an expelling efficiency of $80 \%$ at the speed of $30 \mathrm{rpm}$. However, the power requirement of the machine is $4 \mathrm{~kW}$ and is designed to expel oil from Cashew Nut Shell and can be adapted to expel oil from most oil seed varieties [11]. An expelling machine was developed for extracting oil from decorticated sunflower seeds [12]. The machine has expelling capacity of 24.4 litres/hr. of oil and throughput capacity of $502.64 \mathrm{~kg} /$ day. A sunflower oil expeller with a capacity of 24.431/hr. Evaluation of the machine on sunflower gave an expelling efficiency of $70 \%$ at the speed of $50 \mathrm{rpm}$.

The design and fabrication of oil extraction machine from nuts. The operational and process performance showed that the machine extract well over an average of $62 \%$ of nuts when manually and electrically operated [13],[14]. The wild apricot pits yield 22-38 percent kernels, which may be sweet or bitter depending on the type. An analysis of the kernels gave about 53.4\% oil. Oil extraction from date palm seeds (Iraqi date palm) is done by standard solvent extraction method using a Soxhlet apparatus. It investigated the extraction of palm seed oil as a cheap feedstock for producing bio-oil and determine the fatty acid composition of bio-oil [15].

\section{METHODOLGY}

\subsection{Design Concept}

The design was targeted toward achieving the following, high oil yield, high extraction efficiency, high quality of oil, availability and low cost construction of groundnut oil expeller. Other considerations included the desire to design the cylindrical barrel to accommodate the require quantity of raw material. Also considered is to design the worm shaft to ensure maximum conveyance, crushing, grinding and pressing of the nuts. Consideration was also given for a strong main frame to ensure structural stability and strong support for the machine.

The machine has the following specifications; capacity of $3 \mathrm{~kg} / \mathrm{hr}$ for expelling, speed range between 50 and 100 rpm, screw thread thickness of $5 \mathrm{~mm}$, length of Power screw shaft $600 \mathrm{~mm}$, integral cone length of $120 \mathrm{~mm}$, screw threaded section of $530 \mathrm{~mm}$ length and an extraction chamber with $70 \mathrm{~mm}$ internal diameter and $308 \mathrm{~mm}$ length. The design is shown in Figure 3.

The machine component parts include speed reduction gear, drain collector, chain and sprocket, and the hopper. The expeller is driven by a 1 h.p electric motor via a reduction gear. The expelling unit consists of a screw expellant shaft. The heating of groundnut seeds is achieved by generated heat, which heats the surrounding of seeds passage.

\subsection{Material Selection}

A list of the material selected for the major components of the design is shown in Table 1. The table also shows the specifications and quantity of the material used. While Table 2 shows the components, material selection and selection criteria of the material used. 


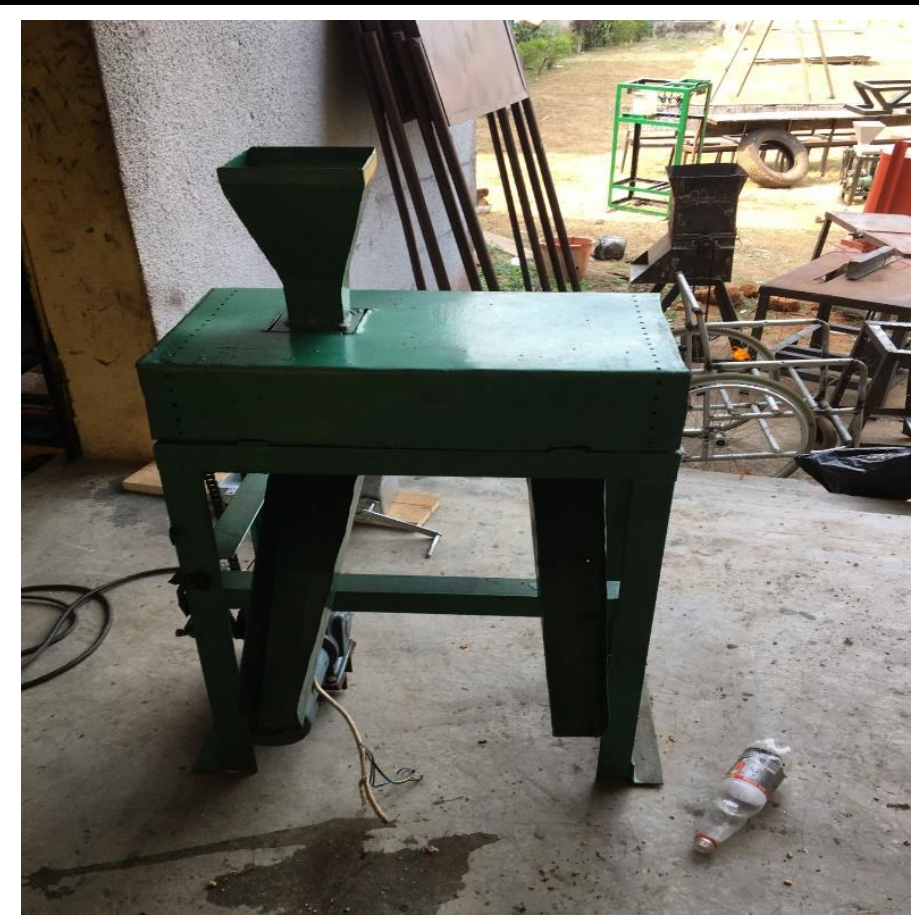

Figure 2: Groundnut oil extractor

Table 1: Specifications and quantity of the material selected.

\begin{tabular}{llll}
\hline S/N & Component & Specification & Quantity \\
\hline 1 & Gear motor & 1 Hp (1400rpm) & 1 \\
2 & Angel iron 50x50mm & $50 \times 50 \mathrm{~mm}$ & 1 \\
3 & 40mm Rod & NA & 1 \\
4 & Circuit breaker & NA & 1 \\
5 & Spocket & $1 / 2 "$ & 2 \\
6 & Chain & NA & 1 meter \\
7 & 2mm thickness mild steel & L x B $(1219.2 \mathrm{~mm} \mathrm{x} \mathrm{2438.4mm)}$ & 1 sheet \\
& Sheet & & \\
8 & 12 mm rod (worn) & NA & 1 \\
9 & Preformed housing & NA & 1 \\
10 & Pillow bearing & $30 \mathrm{~mm}$ & 2 \\
11 & Spring & NA & 1 \\
12 & Bolt & M6 & 8 \\
13 & Bolt & M10 & 10 \\
14 & Electrode & Gauge 10 & 1 pack \\
15 & Grinding disc & NA & 2 \\
16 & Cutting disc & NA & 2 \\
\hline
\end{tabular}

\subsection{Economic Requirement}

This is about the most important factor for the material selection because it determines the total cost of production which in turn affects the price of the product or retail cost and consumer choice. If the total cost of production is high, variably the price of the finished product will also be high. When the price of a product is high, consumers will seek for alternative cheap but similar goods. Bearing in mind that the two aims of production is satisfying consumer wants and needs and also to make maximum profit. 
Table 2 Components, Material Selection and Selection Criteria of the Material Used.

\begin{tabular}{|c|c|c|c|}
\hline $\mathrm{S} / \mathrm{N}$ & COMPONENT & $\begin{array}{l}\text { MATERIAL } \\
\text { SELECTION }\end{array}$ & SELECTION CRITERIA \\
\hline 1 & Expeller screw & Mild steel & $\begin{array}{l}\text { Conventional and strong } \\
\text { and its locally available }\end{array}$ \\
\hline 2 & Bearing supporting bar & Mild steel & Easily machined \\
\hline 3 & Hopper & Mild steel plate & Easily machined \\
\hline 4 & Speed reduction system & $\begin{array}{l}\text { Electric motor, chain and } \\
\text { sprocket }\end{array}$ & $\begin{array}{l}\text { Single phase electric motor } \\
\text { of } 1 \mathrm{hp}\end{array}$ \\
\hline 5 & Angle iron & Mild steel & Locally available \\
\hline 6 & Bolts & NA & Locally available \\
\hline 7 & Bearing & NA & Locally available \\
\hline
\end{tabular}

As a producer one must judiciously select relatively cheap but reliable and appropriate materials for production. This will reduce the overhead cost of production therefor making it cheap in respect to other similar materials. Then we can comfortably harmonize the cost of production with the real price. One of the major consideration in engineering design is to design machines that are reliable, cost effective and the ability of the machine solving human problem. This was one of our considerations in this project work. The table below shows the cost implication of the project;

Table 3: Cost Implication

\begin{tabular}{|c|c|c|c|}
\hline $\mathrm{S} / \mathrm{N}$ & Component & Quantity & Cost (Naira) \\
\hline 1 & Gear motor & 1 unit & 30000 \\
\hline 2 & Angel iron 50x50mm & 1 unit & 10000 \\
\hline 3 & 40mm Rod & 1 unit & 30000 \\
\hline 4 & Circuit breaker & 1 unit & 300 \\
\hline 5 & Sprocket & 2 unit & 2000 \\
\hline 6 & Chain & 1 meter & 1000 \\
\hline 7 & $\begin{array}{l}2 \mathrm{~mm} \text { thickness mild steel } \\
\text { Sheet }\end{array}$ & 1 sheet & 5000 \\
\hline 8 & $12 \mathrm{~mm}$ rod (worn) & 1 unit & 1000 \\
\hline 9 & Preformed housing & 1 unit & 5000 \\
\hline 10 & Pillow bearing & 2 unit & 5000 \\
\hline 11 & Spring & 1 unit & 500 \\
\hline 12 & M6 bolt & 8 pieces & 400 \\
\hline 13 & M10 Bolt & 10 pieces & 1000 \\
\hline 14 & Electrode gauge 10 & 1 pack & 3000 \\
\hline 15 & Grinding disc & 2 unit & 1000 \\
\hline 16 & Cutting disc & 2 unit & 1000 \\
\hline 17 & Emery cloth & Full length & 1000 \\
\hline 18 & Paint & 2.5 litres & 3000 \\
\hline 19 & Hiring of spraying machine & NA & 2000 \\
\hline
\end{tabular}




\subsection{Design Analysis}

Design of hopper: The hopper design is based on the volume of frustum of a pyramid. The volume of the pyramid is obtained by subtracting the volume of a smaller pyramid from that of a larger one as given by Khurmi and Gupta (2004) [16]

$$
V=\frac{1}{3} \pi\left(R^{2} H-r^{2} h\right)
$$

Where $\mathrm{R}=$ outer radius, $\mathrm{H}=$ external height, $\mathrm{r}=$ inner radius and $\mathrm{h}=$ internal height. There values are $175 \mathrm{~mm}$, $350 \mathrm{~mm}, 50 \mathrm{~mm}$ and $100 \mathrm{~mm}$ respectively, when applied a volume of $0.011 \mathrm{~m} 3$ was obtained

Extracting Chamber Design: The extracting chamber is design based on internal pressure in the chamber, the extracting chamber is treated as thin-walled cylinder or vessel as given by Khurmi and Gupta (2004) [16], the tangential stress perpendicular to the axis of the cylinder

$\sigma=\frac{p d}{2 t}(M P a)$

Where: $\sigma=$ perpendicular or hoop stress, $d=$ internal diameter $(50 \mathrm{~mm}), \mathrm{t}=$ thickness $(5 \mathrm{~mm}), \rho=$ internal pressure $=$ force/area of cylinder $=$ F/A.

Where: area of a cylinder, $A=\pi R^{2}$ is obtained as $1963.75 \mathrm{~m}^{2}$

force, $F=\frac{\text { Torque,T }}{\text { length of the chamber, } l}$

Where: Length of the chamber, $l=398 \mathrm{~mm}$

Torque, $T=\mathrm{HP} \frac{5252}{N}$

Where: $\mathrm{HP}=$ horse power, $\mathrm{N}=$ shaft speed $(1400 \mathrm{rpm}), \mathrm{T}=1 * \frac{5252}{1400}=3.75 \mathrm{~N} . \mathrm{m}, \mathrm{F}=\frac{F}{l}=\frac{3.75}{398}=0.0094 \mathrm{~N}$,

$\mathrm{P}=\frac{F}{A}=\frac{0.0094}{1963.75}=4.8 \times 10^{-6}, \sigma=\frac{p d}{2 t}=\frac{4.8 \times 10^{-6} \times 50}{2 \times 5}=2.4 \times 10^{-5} \mathrm{MPa}$

Power Required for Crushing: The power required for crushing is determined from the equation 5 as given by Khumi and Gupta (2004)[16].

$p=\frac{2 \pi N T}{60}$

Where: $p=$ power required in watt $(750 \mathrm{w}=0.75 \mathrm{kw})$

$T_{l}$ is the torque obtained as $119.4 \mathrm{~N} . \mathrm{m}$ for an average shaft speed, $\mathrm{N}$ of $60 \mathrm{rpm}$.

The power required for crushing is given by

$p=\frac{2 \times 3.142 \times 60 \times 119.4}{60}=\frac{45018.576}{60}=750 \mathrm{~W}=0.75 \mathrm{kw}$

The value of $0.75 \mathrm{kw}$ of power is an estimate of the required crushing power at expeller full load. In this work an electric motor of $0.75 \mathrm{kw}$ was used which implies that the motor will power the machine effectively without failure

Expeller Screw Design Consideration: The expeller screw will be subjected primarily to torsion and as a result, torsion and compressive stresses arises in the system.

The torque (T) revolves the screw, which has to overcome the crushing forces in order to bring about the required crushing. The threaded end of the shaft has to be conventional left hand helix thread. This prevents the pressure cone from loosening since the shaft has to rotate in clockwise direction. The threaded end of the shaft is subjected to direct compressive forces. The torque $(\mathrm{T})$ corresponding to the power input is given by the relation. According to Khurmi and Gupta (2004) [16]:

$T=\frac{9.5 p}{N}$

Where: $\mathrm{P}=$ power (watts), $\mathrm{T}=$ Torque $(\mathrm{N} / \mathrm{M}), \mathrm{N}=$ Speed $(\mathrm{rpm})$

The effective length of the expeller screw is about $500 \mathrm{~mm}$. the tonsorial resistance due to crushing effect was given as $2.150 \mathrm{~N} / \mathrm{m}=\mathrm{T} 2$ using $0.75 \mathrm{~kW}$ electric motor, torque produced and delivered to expeller $\left(T_{l}\right)$ shaft can be calculated

$\mathrm{P}=$ power $=750 \mathrm{~W}$ calculated above 
$\mathrm{N}=$ Shaft speed $=60 \mathrm{rpm}$ calculated above

And $T_{l}=119.4 \mathrm{~N} / \mathrm{m}$ calculated above

Since T1=T2 crushing will take place without failure of the expeller shaft

$\mathrm{T} 1=$ Expeller shaft torque $\mathrm{T} 2=$ Average crushing torque

Speed Reduction System Design: The speed deduction unit in this design is made up of belt and electric motor. The electric motor, which is coupled directly to the sprocket which the chain is mounted on, runs at 1400rpm. The electric motor has a power output of $0.75 \mathrm{~kW}$ and is of $50 \mathrm{~Hz}$ single phase type.

\subsection{Methodology of Fabrication}

The machine consists of the following:

Hopper: The hopper is the feed chute with the following dimensions:

Height $=200 \mathrm{~mm}$

Smaller pyramid diameter $=78 \mathrm{~mm}$ and Larger pyramid diameter $=200 \mathrm{~mm}$.

Cylindrical Barrel: This was fabricated to accommodate the required quantity of raw material. The barrel consists of the following dimensions: Length of barrel $=398 \mathrm{~mm}$, Diameter of barrel $=60 \mathrm{~mm}$, Diameter of the perforation on barrel $=2 \mathrm{~mm}$, Thickness of material $=5 \mathrm{~mm}$

Screw Shaft: This is fabricated into the following section; crushing or grinding and pressing section of the nut. Dimensions of the Screw shaft: Length of the shaft $=500 \mathrm{~mm}$, Diameter of shaft $=30 \mathrm{~mm}$, Minor diameter of the shaft $=20 \mathrm{~mm}$ and pitch of the screw shaft $=10 \mathrm{~mm}$

The Frame: The frame supports the machine and is firmly fastened together with bolt and nut to allow easy dismount-ling. The prime mover is a $1 \mathrm{hp}$ electric motor of $1400 \mathrm{rpm}$ with chain and sprocket arrangement. Dimension of the frame, Top $=394 \times 200 \mathrm{~mm}$, Bottom $=540 \times 250 \mathrm{~mm}$, Height $=610 \mathrm{~mm}$, Material $=1 / 2$-inch angle iron

\section{PERFORMANCE EVALUATION}

\subsection{Test Results}

Oil is a valuable product with universal demand, and the possible income from oil extraction is therefore often enough to justify the relatively high cost of setting up and running a small-scale oil milling business as stated by Hans and Frans (1989) [17]. The cell walls of oil seeds encapsulating the oil are characterized by cellulosic and non-cellulosic materials like hemicelluloses, pectin etc. They in general protect the constituents of the cell. In the extraction process the cell wall is ruptured by grinding in order to release oil. Incomplete rupture due to process constraints results in reduced yield [18].

Samples of some fresh shelled groundnut seeds were collected and feed into the machine through the hopper of the machine. The machine was switched on and allowed to run for 8minutes. The result of the first run is showed in the Table 4. As a result of the quality of the oil and cake produced, it became necessary to perform a re-test run. The time allowed for the machine to heat up was increased to 15 and 20 minutes respectively and the result is obtained as in Table 4. The testing result suggests that the performance of the machine is highly depended on the speed of the electric motor and the quantity of material passing through the machine with expelling operation probably better at around 60 revolutions per minute.

Table 4: Test-run result for the machine operation

\begin{tabular}{llll}
\hline Characteristics & First Test run & $\begin{array}{l}\text { Second } \\
\text { Test run }\end{array}$ & $\begin{array}{l}\text { Third } \\
\text { Test run }\end{array}$ \\
\hline Quantity of groundnut & $0.60 \mathrm{~kg}$ & $0.60 \mathrm{~kg}$ & $0.75 \mathrm{~kg}$ \\
Time allow for heating & $8 \mathrm{mins}$ & $10 \mathrm{mins}$ & $10 \mathrm{mins}$ \\
Time of crushing and extraction & $10 \mathrm{mins}$ & $10 \mathrm{mins}$ & $15 \mathrm{mins}$ \\
Quantity of oil & $0.015 \mathrm{~kg}$ & $0.05 \mathrm{~kg}$ & $0.09 \mathrm{~kg}$ \\
Quality of oil produced & Impure & Impure & Impure \\
Quality of cake produced & Dry & Not dry & Not dry \\
Quantity of cake & $0.52 \mathrm{~kg}$ & $0.56 \mathrm{~kg}$ & $0.70 \mathrm{~kg}$ \\
\hline
\end{tabular}




\subsection{Discussion}

Effect of Clearance on Fineness of Cake: The decree of fineness of the ground cake depends on the clearance between the conical elector and the extraction chamber. It was observed that the extracted cake at $1.0 \mathrm{~mm}$ was finest. This observation is due to the fact that as the flow area decreases as the pressure exerted increases. This aids the grinding and compression of the cake against extraction chamber walls, thus producing a fine cake. On the other hand, when the flow area increases, the pressure exerted on the cake becomes relatively small, thus leading to coarse cake.

Capacity Rating of the Machine: The capacity of the machine was established based on the test carried out with the machine.

The average capacity of the machine is calculated from the test results in Table 1, using the feed rates.

Average capacity $=\frac{0.60+0.60+0.75}{3}=1.95 / 3=0.65 \mathrm{~kg}$

Efficiency of the Machine: Efficiency, $\eta \mathrm{m}$ of the machine is obtained from the oil extraction efficiency E, which is given by

$E=\frac{y}{c_{O}} \times 100 \%$

Where $\mathrm{Y}=$ oil yield in percentage.

$c_{O}=$ oil content of nut ( $50 \%$ for groundnut seed-maximum)

The oil yield Y is calculated from, $y=\frac{\left(w_{1}+w_{2}\right)}{w_{1}} \times 100 \%$

Where $w_{l}=$ weight of un-milled groundnut seed

$$
w_{2}=\text { weight of cake (after milling) sample }
$$

Using averages from test results in, $w_{l}=\frac{0.60+0.60+0.75}{3}=0.65 \mathrm{~kg}, w_{2}=\frac{0.52+0.55+0.70}{3}=0.59 \mathrm{~kg}$

$\mathrm{Y}=\frac{0.65+0.59}{3} \times 100 \%=41.33 \%$

Oil extraction efficiency $=E=\frac{y}{c_{O}} \times 100 \%=0.4133 / 0.5 * 100 \%=82.66 \%$

Therefore, Efficiency of machine, $\eta \mathrm{m}=82.66 \%$

\section{CONCLUSION}

A groundnut expeller was developed, constructed using locally available and easily accessible materials, and tested for extraction of groundnut oil. The expeller was simple enough to manufacture, operate, repair, and maintain locally. Powered by a $1 \mathrm{hp}$ three-phase electric motor, the expeller has an average oil yield and extraction efficiency of $82.66 \%$ per cent groundnut seed with N160, 000 production cost. In rural and urban areas, the expeller can be used for small-scale groundnut oil extraction. Based on this technology, a cottage groundnut oil processing plant may make an individual self-employed and also employer of labour.. The groundnut oil produced will be at affordable costs for consumers and also provide cake for livestock feed mill.

The groundnut oil produced will be at affordable costs for consumers and also provide cake for livestock feed mill.

We also tested a machine which expels groundnut oil. The results of the relative performance test show that the machine maintained high levels of oil extraction characteristics in terms of the quality of the cake and oil. The system is inexpensive and could easily fit commercial quantities of groundnut oil into medium and large-scale industry. The system is quick and safe to use, has a low rate of energy consumption and does not pollute the environment. We've finally realized our goal. Although the machine has a higher rate of oil extraction, some need for improvement exists on it.

\section{REFERENCE}

[1] Ogunsina, B. S., Owolarafe, O. K., \& Olatunde, G. A. (2008). Oil point pressure of cashew [Anacordium occidentale] kernels. International Agrophysics, 22(1), 53-59. 
[2] Khan, L. M., \& Hanna, M. A. (1983). Expression of oil from oilseeds-a review. Journal of Agricultural Engineering Research, 28(6), 495-503

[3] Singh, J., \& Bargale, P. C. (2000). Development of a small capacity double stage compression screw press for oil expression. Journal of food engineering, 43(2), 75-82.

[4] Fitch-Haumann, B. (1997). Mechanical extraction: capitalizing on solvent-free processing. Inform, 8, $173 \mathrm{e} 174$.

[5] Zheng, Y. L., Wiesenborn, D. P., Tostenson, K., \& Kangas, N. (2003). Screw pressing of whole and dehulled flaxseed for organic oil. Journal of the American Oil Chemists' Society, 80(10), 1039-1045.

[6] Eliwa, A. A., \& Elfatih, A. (2012). Developing a local extraction watermelon seeds machine. Journal of Applied Sciences Research, (January), 474-482.

[7] Teota, M.S., and T Ramakrishm, T. (1989). Development of Small Scale Equipment for Depulpping Locust Bean Seeds.Densities of Meleon Seed, Kernels and Fluid.Journal of Food Engineering. Vol. 3. No. 1. pp 231 236

[8] Anebi, G. J., Umogbai, V. I. and Obetta, S. E. "Development Of A Soya Bean Oil Extracting Machine" Asian Journal of Science and Technology Vol. 5, Issue 12, pp.782- 788, December, 2014.

[9] Ojolo, S. J., Orisaleye, J. I., \& Ismail, S. O. (2012). Design of a Jathropha oil expelling machine. Journal of Emerging Trends in Engineering and Applied Sciences, 3(3), 412-419.

[10] Chaimae.B(2016), “ Large-Scale Coffee Oil Extraction” Valorization of Waste Coffee Grounds into Biodiesel.

[11] Thierry G. (2016). "Development of an Oil Extraction Machine for Cashew Nut Shell”, International Journal of Engineering and Techniques (IJET), Vol. 2(2).

[12] Bamgboye, A.I and Adejumo, A.O (2007); "Development of a Sunflower Oil Expeller" Agricultural Engineering International: the CIGRE journal, Vol. IX, pp. 1-7

[13] Abdul-Akaba.T, Kantiok.O, Haruma.A (2015) "Design and Fabrication of Oil Extraction Machine from Nuts", Department of Mechanical Engineering, Kaduma, Nigeria, Vol. 6 Issue 1.

[14] Kate, A. E., Lohani, U. C., Pandey, J. P., Shahi, N. C., \& Sarkar, A. (2014). Traditional and mechanical method of the oil extraction from wild apricot kernel: a comparative study. Res. J. Chem. Environ. Sci, 2, 54-60

[15] Ali, M. A., Al-Hattab, T. A., \& Al-Hydary, I. A. (2015). Extraction of date palm seed oil (Phoenix dactylifera) by Soxhlet apparatus. International Journal of Advances in Engineering \& Technology, 8(3), 261.

[16] Khurmi, R.S \& Gupta, J.K (2004), Theory of Machines, Eurasia publishing housing, New Delhi.

[17] Hans, J.W. and Frans, W.K. (1989). "Small Scale Processing of Oil Fruits and Oilseeds" Publication of German Appropriate Technology Exchange (GATE), D-65726, Eschborn, Federal Republic of Germany.

[18] Hammos, R.O. (1994) “The Origin and History of Groundnut” In: Smartt, J. (2nd Ed.), The Groundnut Crop: A Scientific Basis for Improvement, Chapman and Hall, New York, USA 